\title{
The Commodification of Female Sensuality in Indonesian Film Industry: Case Study of Warkop DKI
}

\author{
Debby Dwi Elsha* \\ Department of Communication Science, University of Technology Yogyakarta, Indonesia
}

\author{
Andri Praseto Yuwono \\ Department of Communication Science, University of Technology Yogyakarta, Indonesia
}

\begin{abstract}
This paper is an analysis of the process of commodification of female sensuality in an Indonesianbased film industry. Taking the case of Warkop DKI, a franchise film which continues commodifying comedy, social political criticism, and sexy women in generating profits since 1979. The commodification of female sensuality is displayed through stories, scenes, and shots which highlight parts of the female body as well as interactions between male and female characters that indicate sexual activities. However, in Warkop DKI Reborn: Jangkrik Boss! Part 1 and Part 2 which were released in 2017, the female sensuality was decreased. Applying qualitative method comprising from interviews, film observations and literature studies this paper found out that the presence of female producers does not play a great role in decreasing the use of female sensuality in those industry.
\end{abstract}

Keywords: Film; female; sensuality; commodification; industry

\section{Introduction}

The film industry in Indonesia is growing after a long hiatus Various film genres are produced and get good responses from the public. The development of the Indonesian film industry cannot be separated from the increasing presence of women who contribute both on and behind the scenes. Several women who act as directors and producers are Nia Dinata, Mouly Surya and Lola Amaria. There are also women who play role only as producers or directors. Of course, the role of actress should not be forgotten because the presence of women on the screen is very important to observe. In horror films, the presence of many women is potrayed as a sensual and inviting figure. For example, in the films Arwah Goyang Jupe Depe/ Arwah Goyang Karawang (2011) and Dendam Pocong Mupeng (2010), female sensuality is shown in scenes where female characters make intentional erotic movements, yet are not actually needed in delivering messages. This is intentional to arouse the sexual imagination of the male viewer (Winarno, 2013).

\footnotetext{
"Corresponding email: debbyelsha@gmail.com
} 
Not only in horror films, but comedy films are also quite identical to the presence of sexy women appearing in the comedy genre. In the midst of the emergence of comedy films produced by new filmmakers, in 2016 a surprising achievement was obtained by the film Warkop DKI Reborn: Jangkrik Boss! (hereinafter written with Warkop DKI Reborn) Part 1. This film won the most viewers in the history of Indonesian cinema. With a total audience of 6,858,616, this comedy genre film succeeded in getting rid of romantic drama, action, religious and family films. The film continued with its sequel, Jangkrik Boss! Part 2, which was released the following year with an achievement of 4,083,190 viewers, was far above the average acquisition of Indonesian film viewers which generally ranged between 500,000 to 2,000,000 viewers (filmindonesia.or.id, 2018).

The people have known Warkop DKI since a few decades ago. Warkop DKI is a film which is motivated by comedy activities performed by Dono, Kasino and Indro in radio broadcasts (previously called Warkop Prambors). The word "Warkop DKT itself comes from the word Warung Kopi (coffee shop) and Dono-Kasino-Indro. Warkop DKI film has been produced since 1979 under the title Mana Tahaaan ... With a total of 36 series (a total of 37 including Warkop DKI Reborn 3, released in 2019), Warkop DKI is the only Indonesian film with a total production of up to tens of titles in Indonesia.

Warkop DKI has a peculiarity that is always visible in every film with the element of silly comedy, social political criticism and sexy women. The presence of female actresses in this film is highlighted with scenes that emphasize body parts and body movements showing female sensuality. Eva Arnaz is one of the actresses who became the icon of Warkop DKI by starring in more than five film titles including Manusia 6 Juta Dolar (1981), Maju Kena Mundu Kena (1983), and Pokoknya Beres (1983). In Warkop DKI film, Eva Arnaz often wore sexy clothes showing her body curves and took scenes involving intimate physical contact with co-stars, Dono, Kasino and Indro.

In one scene of Pokoknya Beres film, there is a scene when Dono was lying on Eva Arnaz's body wearing sexy clothes. Similar scenes are also found in other Warkop DKI films. This shows that the sensuality of women is used as an attraction for films that turn into commodities. Female sensuality is transformed into economic value that can produce maximum profit. However, after a long time absence, the appearance of the film Jangkrik Boss! Parts 1 and 2 present these characteristics in quite different ways with a smaller portion of sensuality shows. Even so, Jangkrik Boss! Part 1 actually won a very large viewer to set a record as the best-selling Indonesian commercial film of all time (until now, 2019). Apart from a small or a large portion of its shows, presenting the sensuality of women in Warkop $D K I$ is a form of commodification in the film industry. Thus, research needs to be conducted to find out the background which becomes a consideration in giving efforts to commodify the sensuality of women in Jangkrik Boss! Part 1 and 2.

\section{Literature Review}

The presence of women in many films is portrayed as a figure that cannot be separated from the body element. The female body is used as an attraction with constructed visualization techniques while the film is a product that has been carefully planned and considered from all aspects. Synott (1993) stated that the body can be caressed or killed, it can also be loved and hated, can be considered beautiful and also ugly, can be considered sacred but also dirty. The ideas about the body are formed through the norms derived from people's beliefs about what is good and bad. What is considered good about the body at a time will be agreed upon and obeyed by society until the value of goodness changes and replaced by new criteria.

A female body is an object that can portray sensuality and then becomes a selling value which the viewer enjoys it as an object of view in watching films. Not only related to economics, but the commodification of female bodies in various media of entertainment in capitalist societies also has 
raised various issues that are more related to ideological relations in how the use of female bodies and images signifies a social relationship, especially gender relations constructed based on certain ideological systems (Afneta, 2015 ).

The definition of the concept of sensuality developed in the mass media is not successfully formulated in a clear definition. At the very least, it can be seen that the assumptions developed in society generally state that sensuality refers to actions that are intentionally exhibited to invite sexual imagination to anyone who consumes them. Wearing mini and sexy clothes are some of the things that shape the concept of sensuality itself. The concept of sensuality is very closely related to the ability of the five senses in capturing certain objects. Usually the visual object is the most powerful form of the concept of sensuality (Ida and Surya, 2002).

Primada Qurrota Ayun (2015) found the commodification of female sensuality in Indonesian horror films. She stated that the appearance of sensuality and female body in horror films showed that women experienced violence and oppression caused by a power system in various forms indirectly. Horror films employing women indirectly commit acts of work discrimination and remuneration. Women are made as objects that are sexually abused, depend on men, and there is an unbalanced division of roles in social roles. Commodification of female body is also one form of exploitation carried out in the film Air Terjun Pengantin (2009).

Air Terjun Pengantin makes women as a trade object that has an exchange rate solely for commercial gain. The commodification of the female body is carried out without considering the effects of the film on the public. This is presented through the female body exploitation in various scenes pointing out certain body parts such as the lips, chest, shoulders, and hips. In fact, this film with no doubt presents kissing scenes with body language and expressions supporting the formation of female sensuality. Sensuality is also visualized by presenting women in various characters such as seductive, sexy, and aggressive. Beside sensual movements, sexy clothes like bikini, hairdo, and added by closeup shooting techniques of certain body parts (lips, chest, shoulders, and hips, as well as kissing scenes ) show women as objects of view of men in this case (Pratama, 2014).

In viewing every picture in the film, the viewer must realize that the film is not only seen as a work of art, but also as a medium that presents entertainment and political propaganda tools. This then makes the film have considerable implications when viewed from social, cultural, historical, political and economic aspects. One of the implications created by film is to create a social construction which as if it presents a reality, but instead shapes the public's knowledge of one thing (Kurnia, 2006). Meanwhile, the role of women in the film industry during the New Order, mostly only went to acting (Sen, 1994). When a woman only acts as an actress according to the direction, the woman will be subject to the construction of the image of the woman the filmmaker wants to present. After the fall of the New Order Regime, female filmmakers began to present new ideas representing culture in Indonesia from another perspective.

Hughes-Freeman in Kurnia (2017) argues that currently the representation of women in Indonesian films is becoming more varied and complex. Women can put forward their identity as women in making a film, so they position themselves as agents to voice women's issues or tell stories in their perspective.

The women in the film Arisan! 2 (2011) are represented in the form of a beautiful, intelligent, fashionable, sophisticated, consumptive, independent. Women also portrayed as sex fantasy object but in many aspects are opposed to traditional portrayals. This image is inversely proportional to women who still hold traditional eastern cultural values such as ethics, morals and behavior, for example women who wear mini and tight clothing are considered inappropriate in society (Haryanti and Suwana, 2014). 
In the latest Warkop DKI, although there are differences in the characters and social roles of female characters in Maju Kena Mundur Kena (1983) and Warkop DKI Reborn: Jangkrik Boss! Part 1 (2017), physical depictions of female characters in both film are still similar such as fair skin, black hair, ideal body, and clothing that shows curves. This shows that although there have been films that represent women as creatures who have good bargaining positions, independent and modern, the practice of commodification of female sensuality is still on the agenda in the film industry in Indonesia (Bertilia, 2017). Erdiyanto and Erdinaya (2004) also stated that the film industry is a business industry. This predicate has shifted the assumption of people who still believe that films are works of art produced creatively and fulfill the imagination of people who aim to achieve perfect aesthetics. In practice, film is an industrial, moneymaking product and for sake of profit, this industry breaks the artistic norms of film itself.

The determinant of this business direction is people who have power in the film industry. The biggest holders of power in national films are producers and directors. In many relationships they work in pairs based on compatibility. If the director produces a good and best-selling film, the honorarium will increase, but the creative space remains largely controlled by the producer (Said, 1989). The film production process will be closely monitored by the producer to produce a whole show that the viewers watch and of course after it goes through the censorship process of the censorship agency. Although official announcements made by the government emphasize that government censorship concerns sex, violence, and the protection of the nation's culture, in fact these elements are relatively small in portion. The 1977 Censorship Guidelines contain only one reference about sex on the list consisting of 24 criteria forbidding or cutting film: a warning to "films that emphasize sex and violence".

In 1981, through a seminar, the film industry made the National Film Production Code of Ethics. The purpose of this code of ethics is to ease the "burden" of the censor agent. Before entering the censor, the film industry has understood the limits of their film. Some considerations in the code of ethics are: (1) virtuous entertainment, (2) prohibition of immoral scenes, (3) accentuating humanist values, (4) prohibition of dramatic contradictions of good and evil. The resulting code of ethics is also intended to keep Indonesian human ethics. It reflected which rules are allowed and which ones should be avoided because it can offend the ethics and culture of Indonesia, such as (1) the sanctity of marriage institutions, (2) prohibition against justifying adultery and sexual disorders, (3) prohibiton against displaying sex scenes both as stimuli and activities.

The seminar aims at building self-censorship among film workers. Despite the emphasize on prohibition on pornography, the films produced in the 1970s and 1980s were actually very thick with such scenes. Filmmakers have a pragmatic way of thinking, they featured brave artists in "open-up" scenes, to shortened the production time with a makeshift scenario. The tradition of writing a good scenario eventually did not develop in Indonesia (Nugroho and Suwarto, 2015). In the Regulation of the Minister of Education and Culture of the Republic of Indonesia Number 14 of 2019 concerning Guidelines and Criteria for Censorship, Classification of Audience Age, and Withdrawal of Films and Film Advertisements from Circulation in Article 12 states that films categorized as containing pornography include nude visuals and close-up angles of shooting certain body parts that arouse lust.

\section{Assumption and Question}

Jangkrik Boss! Part 1 and 2 are franchise films from the Warkop DKIseries that reach a very large number of viewers and even Part 1 is able to win a film record with the most viewers of all time. These two films still carry the typical elements of Warkop DKI film of comedy, social and political criticism, and sexy women. However, the portion of female sensuality shows is less than the previous series, for example in Pokoknya Beres. In the previous series, the film was produced by male directors and producers. 
Meanwhile, Jangkrik Boss! Parts 1 and 2 were directed by Anggy Umbara and produced by HB Naveen and Frederica. As one of the producers who directs and controls film production from the beginning to the end with a commercial profit orientation, Frederica certainly has a stake in the goals and considerations and decisions influenced by her thoughts and attitudes related to the culture she professes in everyday life. The sensuality shows presented in this film are influenced by her decision as a producer. Frederica is also a representative of the Falcon Pictures production house that produces Jangkrik Boss! Part 1 and 2 (as well as the latest series of Warkop DKI Reborn 3).

In the producing films as a producer and/or director, the women have a big role in providing the story idea, so it becomes an audiovisual product. Whatever is seen by the viewers is not a series of images that can just happen because the production process includes the agenda of pre-production, production and post-production. It has been planned and improved repeatedly to achieve the goals desired by filmmakers as producers.

In the era before the fall of the New Order regime many films were masterminded by men with patriarchal ideology (including Warkop DKI films), so the presence of women who had an important role in film production could have an influence on production patterns including ideas, concepts and film packaging. In this study, Frederica as a producer is considered to have contributed to the reduction in the manifestation of the commodification of female sensuality in Jangkrik Boss! Part 1 and 2. It is necessary to observe how the decision making process and considerations made by producers, so it affects the presentation of female sensuality in Jangkrik Boss! Part 1 and 2. Therefore, we can know the background of the manifestation of the commodification of female sensuality in the two franchise films.

\section{Theoretical Framework and Method}

A serial film or franchise film is a series of films consisting of at least two or more films with continuity, both the story and the characters in the story. A film franchise is not always in the line with the quality of the film. The viewers do not really care whether the film is good or not, the most important thing is they can watch how their favorite character acts out. In fact, franchise films that get bad criticism can also achieve commercial success (Pratista, 2016).

Film as a product of the media industry has an interest in making maximum profits. To control such a large cost with the risk of loss if the film is not in demand in the market, it is necessary to have an effort to point out the film advantage as a selling point to generate profits. In the 1970s, the filmmakers have a pragmatic way of thinking, capitalized by artists who dared to do vulgar scenes, so the production time could be shortened with improvised scenarios (Arief et al, 1997). The tradition of writing a good scenario also did not develop in Indonesia (Nugroho and Suwarto, 2015). Technical limitations faced by the domestic film industry made Indonesian films emphasize more on the aspect of commodification of matters related to the content and the way of film presentation especially the visual aspect.

Commodification is a process of making something that was not previously a commodity so it turns into a commodity. According to Barker (2005), commodification is a process of association with capitalism, i.e. objects, qualities and signs made as commodities. Meanwhile, commodities are something, the main purpose of which is to be sold to the market. Vincent Mosco (1996) explains that in the political economy the media of commodification is defined as the process of transforming usevalues into exchange rates. The political economy of media is a perspective on the power of capital owners and politics as the basis of the economy and ideology of the media industry in meeting the needs and satisfaction of the public that is marked by compromising to the market through commercial "cultural" products. Mosco divides commodification into three things; the commodification of content, the commodification of audiences or public, and the commodification of workers. The female 
characters in the film are workers who can be used as commodities. Commodification of workers can be in a form of labor exploitation, sexuality and sensuality.

Sensuality is rooted in the word 'sense' which means the senses. According to Kamus Besar Bahasa Indonesia (Indonesian dictionary), sensuality is everything about the body. Sensuality can also be interpreted as the level of an individual's sexual imagination about the object he sees. Sensuality in this research focuses on the presentation of sexual activity as seen from gestures and body language and women's clothing styles that are considered arousing sexual desire.

Laura Mulvey (1999) explains that the patriarchal system controls the production of outstanding films. She criticized this using the psychoanalytic approach and stated that the existence of female characters in the film is not as a creator of meaning, but only as a bearer of the meaning of the message conveyed by the film. In dark cinema conditions, viewers can freely watch without worrying about being seen by others. In more detail, scopophilia in the film is a pleasure obtained by the viewer when viewing women in the film as objects of their views.

Another behavior of the viewer is narcisstic identification. It occurs when the viewer identifies himself as the main male character in the film scenes being watched. The male viewer seemed to get full control over the female cast in the film. Mulvey also stated that since the time of classical Hollywood cinema, women have only functioned as icons. Women are erotic objects for men, both for male characters in films and male viewers who place themselves as active subjects. This causes the camera to be a representation of male gaze in the film. What is captured and displayed on camera represents and meets the expectations of male producers and male viewers.

The sensuality created visually through fashion and clothing also makes male more interested. Everything received through the view of men is more directed to sexual desires which are considered as seduction from a woman. Berger stated that the formulation or description regarding the situation that exists between men and women is "men act, women act". Men here are characterized by a more active role, while women have passive role and being observed. Women must always be vigilant and pay attention to their appearance on men eyes (Berger, 1972, in Barnard, 1996).

In this study, female sensuality is observed from the appearance and treatment of a female body that can be seen from costumes, make-up and hair do, gestures or body movements, and the voices of female characters related to the shooting techniques in the film under study. Problems raised in this study will be analyzed using qualitative methods with a case study analysis. Case study is one of research methods in the social sciences. In general, case study will be more appropriate strategy if the main question of a study is related to how or why, if the researcher has little opportunity to control the events investigated, and if the focus of his research lies on contemporary (present) phenomena in real life context (Yin, 2014).

Case study is chosen as a type of qualitative research that will reveal the role of women as a filmmakers. Besides, it will also explain the reasons behind the commodification process carried out as filmmakers who convey the messages of female sensuality in the films studied. By observing Warkop $D K I$ films and interviewing Frederica as the producer representing Falcon Pictures production house and Anggy Umbara as director, this research focuses on the process and purpose in presenting the sensuality of female characters in the Warkop DKI Reborn Part $1 \& 2$ (as Warkop DKI produced by women) related to the attractiveness and economic value of the film.

\section{Discusssion}

\section{Film Market}

Warkop DKI Reborn Part $1 \& 2$ are comedy film that targets all ages and all groups. The film is by designed entertaining so that it reached more than 2 million viewers of Warkop DKI Reborn Part 1. 
entertaining, so it is expected to be a pleasant treat for everyone who watches it. This film is also expect to capture as many viewer as possible and also widen its scope of viewer. Frederica said that based on the analysis of cinema viewer data, there were more than 2 million viewers of Warkop DKIReborn Part 1 film who had never been to the cinema at all. These people are viewers from the lower class economy such as pedicab drivers and noodles seller who don't even know how to flush the toilet. Falcon Pictures conducted a large-scale promotion to advertise Warkop DKI Reborn Part $1 \& 2$. They advertise the movie by displaying the trailer not only on TV, but also videotron media on the roadside. The promotion is carried out widespread, above the line and below the line.

\section{Hi Sexy Lady, Show Your Charm!}

Previous Warkop DKI films (released in 1979 to 1994) featured scenes showing the actress' curves clearly while still wearing clothes. Female characters wore mini clothes that clearly shows cleavage and thighs. The sensuality of women can also be seen from scenes showing female gestures that invite lust, where the movements are actually not needed or can be replaced by other movements. In Maju Kena Mundur Kena (1983), there was a scene when Dono kissing Eva Arnaz's cheek repeatedly. In the volleyball scene, Dono hugged and held the butt of several extras as an expression of celebrating victory.

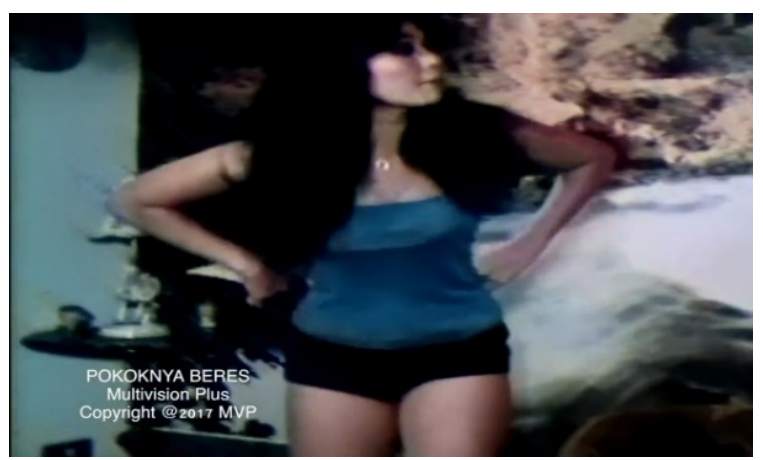

Picture 1. One of the scenes showing Eva Arnaz's curves in Pokoknya Beres. (Author's Compilation).

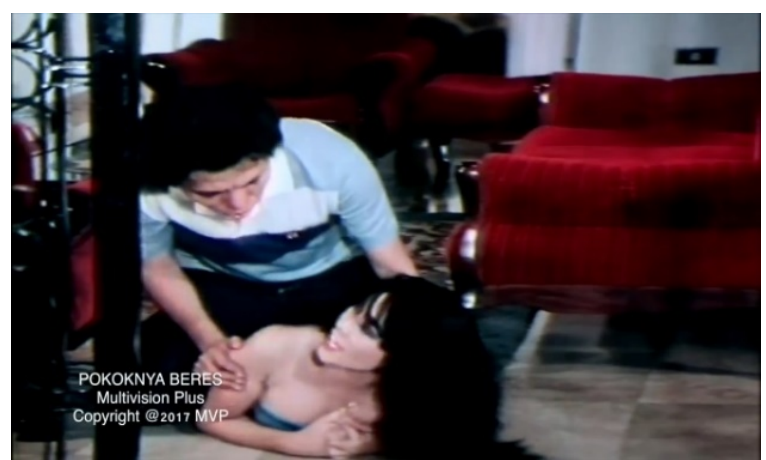

Picture 2. One of the scenes showing the physical interactions of Dono \& Eva Arnaz in Pokoknya Beres. (Author's Compilation).

The storyline of Warkop DKIReborn Part 1 is very easy to understand. Some of the female characters in this film are Sophie (Hannah Al Rashid), Nikki (Nikita Mirzani) and Nadia (Nur Fazura). In addition, there are extras (some household assistants) who appear in sexy clothes and flirty body language. Moreover, there are also extras women who appear wearing beach clothes. There is a censored scene, but it is not something related to female sensuality. It is a scene where the pants of a male character are sagged, and the butt are visible, so they need to be blurred. This incident was unintentional and indeed did not exist in the scenario, but it was considered funny and then it was decided to be included in the film (the result of the interview of director Anggy Umbara, 2019). The Film Censorship Board (LSF) also requires an age limit of 13 years and above. 


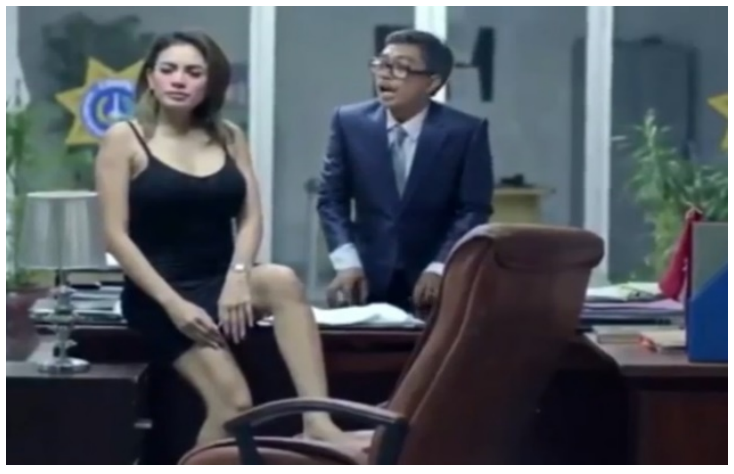

Picture 3. Nikki wearing sexydress at Warkop DKI Reborn Part 1.

(Author's Compilation)

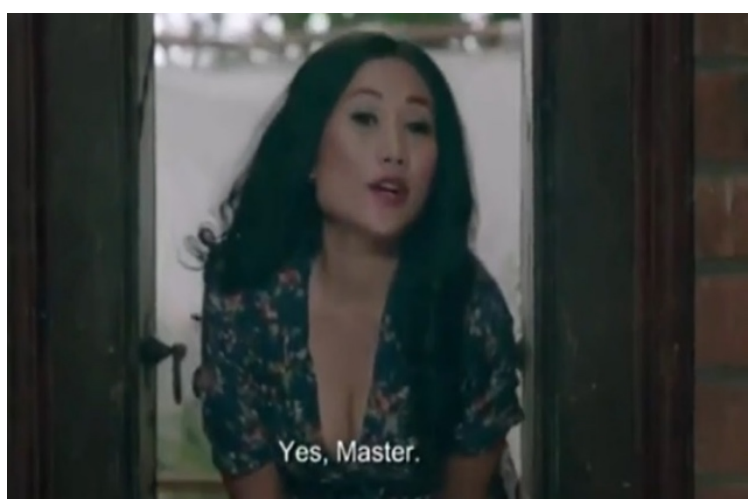

Picture 5. Shot shows the cleavage of an extra inPart 1.

(Author's Compilation)

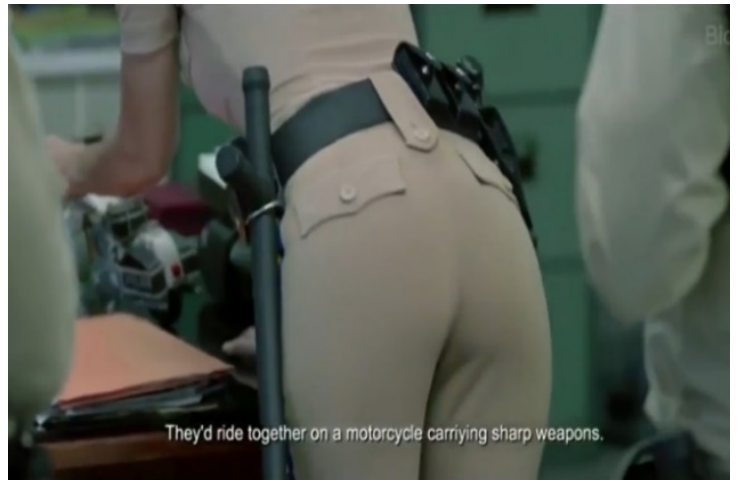

Picture 4. Close up shot: Sophie's butt at Warkop DKIReborn Part 1.

(Author's Compilation).

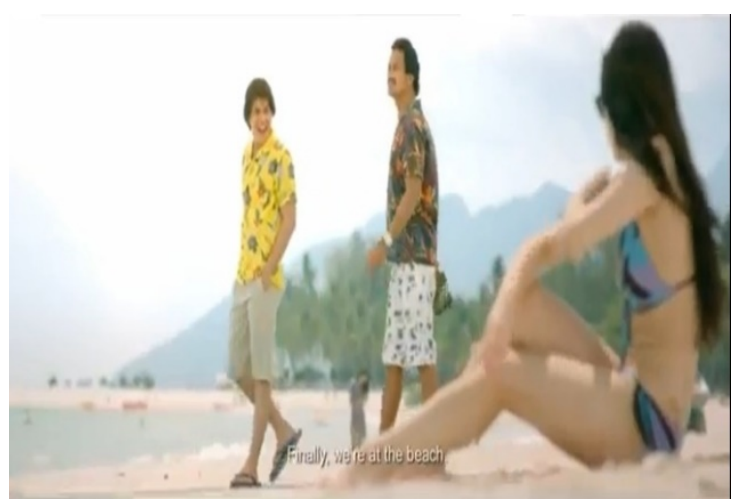

Picture 6. Shot shows a bikini woman in Part 2. (Author's Compilation)

Warkop DKI Reborn Part $1 \& 2$ also present scenes showing female sensuality like the previous films. However, the number of show portions and the intensity is reduced. Image 7 shows the CHIPS uniform outfit (Dono, Kasino and Indro's office) worn by Sophie has a tight cut with a low cleavage and with a different material color i.e. women's uniforms have a nude color. This color accentuates the curves more and gives a greater sensual impression because it is more like the skin color so as if you can imagine Sophie not wearing clothes. The use of this costume is one of the elements to realize the commodification of female sensuality.

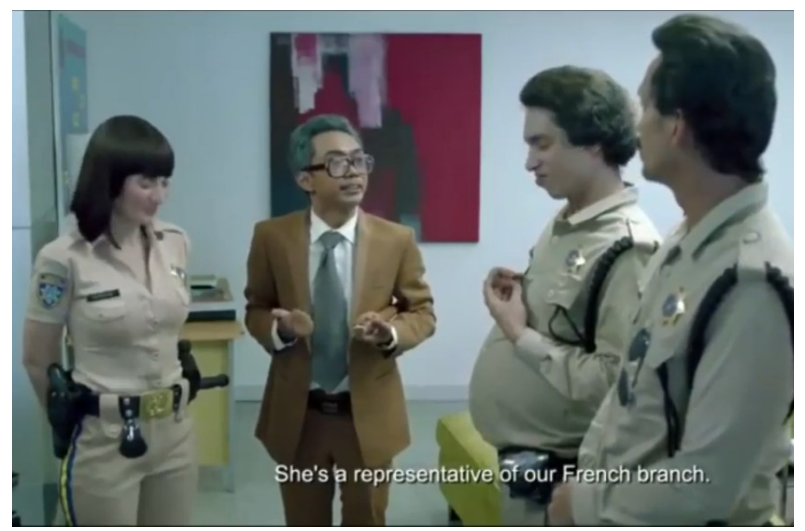

Picture 7. Scene showing CHIPS uniforms of different male and female members.

(Author's Compilation) 
The producer assumes that the essence of Warkop DKI must exist based on what the public knows about the characteristics of Warkop DKI. According to her, she could have produced films with vulgar scenes such as in the 1980s, but such style of film could not be brought about in producing the film Warkop DKI Reborn Part $1 \& 2$ because she had to adjust to the current situation. Indeed, in the 2000s Indonesian films still showed vulgar scenes with the use of female character costumes that were quite sexy as in horror films.

If we really want to make film with vulgar scenes, just do it now. In the early 2000s there were a lot of horror films with vulgar scenes, but there were less and less recently. Even the horror is not showing vulgar scene but showing shock, so the trend is changing”(Frederica's interview).

The trend also changes when the culture and conditions in society have changed to become more religious. Films with Islamic values content are increasingly being produced. The religious element is also a commodity for films that are currently present on the big screen in Indonesia. In film, the presence of the hijab has enriched the ideas and to raise the themes of identity and plurality, while in the applicative media of arts such as film, the position of the hijab is exposed in many Islamic religious films. Hijab is no longer just an attribute of Muslim women to meet the demands of Islamic religious law and propaganda tools of Islamic teachings, but also is a profitable business commodity, both for producers, directors, actors in films and owners of hijab fashion business (Latifah, 2017).

In 2017, censorship of TV shows became very excessive. An example is a cartoon character named Sandy in SpongeBob SquarePants series. The female squirrel was wearing a bikini in the sunbathing scene on the beach. Sandy's body was blurred. It's very absurd. Also, Shizuka's character in the Doraemon series was blurred for wearing a swimsuit while on vacation at the beach. This absurdity is indeed not 100 percent the fault of the LSF which is under the auspices of the Indonesian Broadcasting Commission (KPI). Many blurry actions in this television program are also based on the impulsive act of keeping it safe for the right owner of the program or television station. Because they do not want to have problems with censorship, then do self-censorship that is actually excessive. However, this proves that LSF's performance has not been good because if the instruction, socialization and consultation run well, the owner of the film and the program can take wiser actions in accordance with the applicable provisions.

Of course, films are also not free from this absurd censorship, so making non-vulgar films makes the position of the film safer and can be watched by many people. Although lenient censorship is still often found as seen in the scene seen of image 4 in which the camera highlighted Sophie's butt as the main female character. This of course contradicts article 12 on the category of pornography and it is prohibited related to the element of intentional point (d) "the angle of close-up shooting of certain body parts that arouse lust". In fact, it was very clear that the male character stared at Sophie's butt with such enthusiasm.

Sophie's charm with all the sensuality that has been described is in fact only a weapon to trick Dono, Kasino and Indro. Sophie is part of a group of criminals who run after the treasure. Compared to the Hollywood film franchise which also shows the sensuality of women as a commodity, there is James Bond film produced for 24 series by EON Production. In its final series, Spectre (2015) still presents female sensuality shows that are displayed through costume, gestures, and sexual activities of Bond Girl characters. However, Spectre is a different film from the previous James Bond film series. Spectre represents women who are independent, logical minded and able to make decisions. Women can have a career, make a decision and look according to their taste. This film represents the ideology of 
postmodern feminism that appears from narrative and cinematic elements. Women are not portrayed as dominant figures in order to show the existence of power that oppresses patriarchal domination. The otherness of women is presented as a way to exist and make changes (Elsha, 2019).

\section{Business is Business}

The involvement of producers in the film production is very comprehensive from the beginning to the end. Frederica explained that the phase of script development was carried out by writing a synopsis, the plot scene then proceeded to draft 1. During the script development there was a discussion between the producer, director and scriptwriter. The idea of the story of Warkop DKIReborn Part $1 \& 2$ was brought by the director. In the phase of scene plot, the discussion led the selection of the focus parts that would be developed in the film or eliminated. With the approval of the producer, the writing of the scenario was then carried out by Bene, Andi Wijaya and Anggy Umbara.

Planning before production must be conducted carefully to avoid any production errors, so the process of re-shooting does not need to be done. This relates to the management of a very large film production budget because in one day filming requires up to hundreds of million rupiahs. And obviously, the producer really avoids the production extra budget. As a film industry actor, the producer will run the economic principle of spending as little money as possible to get the maximum profit. This also underlies the making of the film Warkop DKI Reborn:Jangkrik Boss! into two separate parts in one continuous story idea. In fact, these two films can be made in one film with a solid plot. However, by splitting the film into two parts, it will gain more profit because the viewer is curious about the continuity of the story. Even though the viewer of Part 2 is decrease around 2 million, still the acquisition of 4 million viewers is a very good achievement compared to other Indonesian films.

To reach the viewer, producers usually choose to work on films that already have popularity based. What is already well-known and liked by the public is considered to be interesting to watch the film in the cinema. Therefore, after more than two decades it was never produced anymore - but it is still remembered and liked by the public - Falcon Pictures initiated the idea to make a new version of Warkop DKI film and appointed Anggy Umbara to make a story idea and then to direct it. The producer will suppress the production process in the shortest possible time. Anggy Umbara said that in general the producer gave the entire production time (covering pre-production, production to post-production) within 6 months. In fact, according to him, to produce a film time of 6 months is not enough.

In the film making, the director has an authority to decide the location, make up, costume and so forth, so any decision must be based on the director's approval. Then the director's decision will be the proposal for the highest decision maker, the producer. For every producer's command, the director and crew must obey it. The producer also has an authority in the selection of the cast. The cast is then directed to do scenes that are in accordance with the story script. At the editing table the director and producer made an agreement on the whole picture arranged in one whole film. Not only do the commodification of content that is marked by story content that leads to the sensuality of women, the form of the commodification of workers can also be seen from how the actress is asked to perform movements that highlight the parts of her body to produce images that show the sensuality of women.

\section{Viewing Women}

Although a director has the responsibility to direct the film completely including acting directives, movements and voices, costume selection and the use of makeup and hairstyles for female characters in this film, but all final decisions are in the producer's hand. The producer may give orders to exclude 
shots that show the sensuality of women or at the very least if she really aims to carry the characteristics of the previous Warkop DKI film, she can also instruct director to manipulate the scene so that the attractiveness of women is displayed in different ways which ultimately demands cinematic creativity. This shows that female producer also allows other female (actresses) as objects of male vision. Thus, there is no significant difference in treatment compared to male producers producing previous Warkop DKI films.

Frederica said that the film producers prioritize female as the target of film market. This is done because it is believed that women decide what to watched. If a woman wants to watch a movie, she will invite friends, boyfriend, and even the whole family. At least, the general logic that can be accepted is when one woman wants to watch a movie, then at least two tickets are sold. Therefore, with a strict orientation to get the maximum profit, film story ideas must be adapted to women's tastes. This argument is also confirmed by Anggy Umbara's statement stating that without realizing it, the center of the film's production is women.

"This is why there are fewer viewers of action films, because women don't like watching action films. If the producer is invited to produce an action film then the answer will be ouch..... "(Anggy Umbara's interview)

The director stated that during the shoot, the producer did not interfere much with the shooting process and handed it over to the director. At the editing phase, they together agree on which scenes need to be fixed or removed. Because they do not assume there are vulgar scenes, only limited to showing cleavage and similar images, then the film is considered safe. There is no confrontation on the producer's side. Here, both men and women agree with the presentation of female sensuality in Warkop DKI Reborn Part 1 \& 2.

"Yes, the conversation usually happens after the editing process. During the filming there is no conversation, all the scenes aren't vulgar, just, cleavage, cleavage, right, then for part 2 there is a little vulgar scene, a beach scene, but even so it's really short and not from the front angle, so we always see from the side, bikini right? Then err... there was a discussion at the beginning, then when we were editing, we viewed as long as it didn't make people who are too desirous, well, in my opinion it's quite that much, but the producers also follow it, follow. They must also think of it in censorship, right... "(Anggy Umbara's interview)

During this time, patriarchal culture is considered as a culture which only driven by men. It is considered reasonable for Warkop DKI films and films from the 1970s to 1980s to be attached to images that enhance females sensuality. However, when the film is produced by women for example Warkop DKI Reborn Part $1 \& 2$, the film presentation is not much different. The changes in this film (the reduced portion of sensuality shows) also occur only because of changes in social conditions and ongoing trends. On the other hand, it is undeniable that there are some women who enjoy shots that show their curves clearly, scenes that show body movements and a sighing voice so that sensuality is very visible. It cannot be denied, naturally women and men have desires and attractions towards the opposite sex. Thus, efforts to show their existence in terms of sensuality and sexuality are indeed natural. However, regardless of whether an actress likes the scenes she voluntarily performs or not, the act of displaying female sensuality which aims to be the attraction and value of a film as an industrial product is a manifestation of commodification. 
Anggy Umbara explained that during the shooting process there were female actresses who were perfectionist in their appearance. They always felt insecure about her make-up, and always tried to be beautiful so that she becomes idol. This attitude is certainly common in which women always try to look beautiful, for example in a photo session. Even for a selfie, you will repeatedly take pictures in order to get the best results-and coupled with the editing process currently provided by free applications.

Women may argue that the attitude to always look beautiful, sexy and seductive is a form of freedom of expression and conscience. However, they actually adhere to the trend of beauty standards. In portrayals in various media including films, beautiful women are described as slim women or at least, their curves are still clearly visible, such as the waist, curved back to the butt and, most of all, fulllooking breasts. In fact, many times, the film depicted how men make fun of women whom they consider unattractive with a dirty appearance, no makeup, curly hair, large body and dark skin (especially in the Asian region). There will be a very clear dialogue or expression on how the man (often with his peer group) swears that he will not and does not want to make the woman who is considered unattractive as his partner.

These beauty standards have become a myth about beauty that is believed and used as a guide by most women. In fact, these standards are a form of male domination in a patriarchal culture that is deeply rooted and influences various aspects of life, including the fashion and film industries, where from the beginning of the presence of the industry, it was men who held power. Therefore, the imperishable culture with patriarchal ideology in the film manifested in the commodification of female sensuality is not only caused by men's desires, but also by actresses who derive pleasure from their position as objects of view and female producers who follow the tastes of society in patriarchal culture. This is equal to the activity of discussing about women in which the female participant only followed the coversation direction by men only. If they are obedient, they may join.

\section{Conclusion}

The presence of female producers did not make any significant change to the commodification of female sensuality in Warkop DKI. The background of this commodification are: first, retains the characteristic of the film. Second, the portion of female sensuality in Warkop DKI Reborn Part $1 \& 2$ is a form of adjustment to the current trends and culture. This is done base on filmmakers' assumption, both female and male, that presenting women bodies is a natural things as long as it is in accordance with the prevailing cultural boundaries. Third, the film still comply with applicable cencorship regulation.

The LSF should be stricter and in accordance with established regulations. Thus, film producers put orientation more on film quality both in terms of narrative and cinematic. The efforts to produce good films do require good synergy from various parties. Each section needs to realize that the film produced greatly influences the culture that develops in society. For this reason, socialization of media literacy is very needed. A patriarchal culture that puts women as merely objects of view can be abolished by representing women in films as empowered human beings and more than just a source of sensuality. As long as the effort of presenting the female body as a natural attraction of films, by both male and female filmmakers, the commodification of female sensuality of Indonesian film industry is likely to continue. 


\section{References}

Afneta, Andrine Prima. (2015). Komodifikasi Kebertubuhan Perempuan Dalam Wacana Erotika dan Pornografi pada Tayangan Televisi. Jurnal Komunikasi Indonesia, 4 (2), 127-139.

Arief, Sarief M., dkk. (1997). Permasalahan Sensor dan Pertanggungjawaban Etika Produksi.Jakarta: Badan Pertimbangan Film Nasional.

Ayun, Primada Qurrota. (2015). Sensualitas dan Tubuh Perempuan dalam Film-film Horor di Indonesia (Kajian Ekonomi Politik Media). Jurnal Simbolika, 1 (1), 10.

Barker, Chris. (2005). Cultural Studies Teori dan Praktik (terjemahan: Tim Kunci Cultural Studies Centre). Yogyakarta: PT Bentang Pustaka.

Barnard, Malcolm. (1996). Fashion as Communication. Terj: Idy Subandy Ibrahim dan Drs. Yosal Iriantara, MS. 2009. Yogyakarta: Jalasutra.

Elsha, Debby Dwi. (2019). Representasi Perempuan Dalam Film Spectre. Jurnal PIKMA. 2 (1), 3-13. Ida, Rachmah \& Surya, Yuyun Izzati. (2003). Politik Tubuh Dan Sensualitas Perempuan: Diskursus Media Terhadap Fenomena Goyang Penyanyi Dangdut Perempuan. Universitas Airlangga, Surabaya.

Film Indonesia. (2018). Data Penonton. August 14, 2018, retrieved from http://filmindonesia.or.id/movie/spectator/2007-2018\#.W3NGH-gzbIU.

Haryanti, Astrid \& Fiona Suwana. (2014). The Construction of Feminism In Indonesian Film: Arisan! 2. Procedia - Social and Behavioral Science, 155 (2014), 236-241. doi: 10.1016/j.sbspro.2014.10.285

Kurnia, Novi. (2006). Lambannya Pertumbuhan Industri Film. Jurnal IImu Sosial dan IImu Politik, 9(3), 271-196.

Kurnia, Novi. (2017). Consuming Gender and Disability in Indonesian Film. Jurnal ASPIKOM, 3 (3), 570587.

Lathifah, Siti Nur. (2017). Komodifikasi Hijab Dalam Film Religi Islami Layar Lebar Indonesia (Undergraduate Thesis, Universitas Brawijaya , Indonesia). Retrieved from http://repository.ub.ac.id/8384/

Mosco, Vincent. (1996). The Political Economy of Communication: Rethinking and Renewal. London: Sage Publication.

Mulvey, Laura. (1999). "Visual Pleasure and Narrative Cinema". Film Theory and Criticism: Introductory Readings. In Leo Barudy and Marshall Cohen (Eds.) Newyork: Oxford UP.

Pratama, Dio. (2014). Eksploitasi Tubuh Perempuan Dalam Film "Air Terjun Pengantin" Karya Rizal Mantovani”. eJournal IImu Komunikasi, 2 (4), 297-311.

Pratista, Himawan. (2016). Memahami Film Edisi 2. Yogyakarta: Montase Press.

Nugroho, Garin \& Dyna Herlina Suwarto. (2015). Krisis dan Paradoks Film Indonesia. Jakarta: PT Kompas Media Nusantara.

Puteri, Bertilia. (2017). Representasi Perempuan Dalam Film Maju Kena Mundur Kena (1983) dan Warkop DKI Reborn: Jangkrik Boss! Part 1 (Undergraduate Thesis). Universitas Airlangga, Indonesia.

Sen, Khrisna. (1994). Indonesian Cinema : Framing the New Order, London: Zed Book.

Synott, Anthony.(1993). Tubuh Sosial. Simbolisme, Diri, dan Masyarakat. Yogyakarta: Jalasutra.

Said, Salim. (1989). Profil dunia Film Indonesia. Jakarta: GrafitiPers.

Winarno, Andhika Martha. (2013). Representasi Perempuan Dalam Film Horor Indonesia (Undergraduate Thesis). Universitas Airlangga , Indonesia.

Yin, Robert K. (2014). Studi Kasus: Desain \& Metode. Depok: Raja Grafindo Persada 